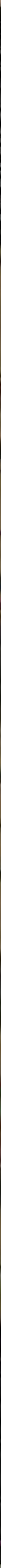

\title{
18
}

\section{B 3129857}

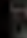




\section{AGRIC. \\ TIBRAIRY $Y^{\text {LBRARY }}$}

被tivetritu of

.No.

$11555 y$

Division

Range

Shelf.

Received May 22, 18:6.

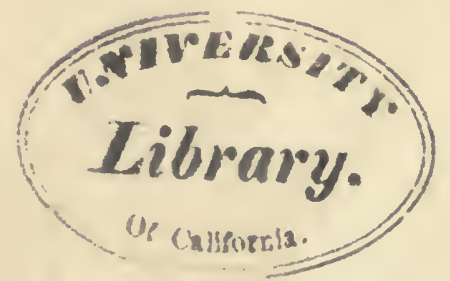


Scientific Eoucation in its Pelations to ênoustry.

\section{AN ADDRESS}

DELIVERED AT THE TWENTY-FIRST ANNIVERSARY

or

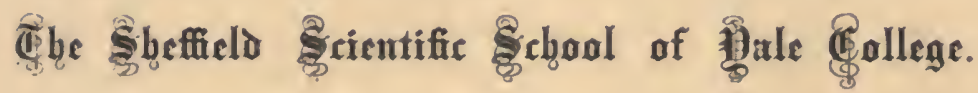

JULY 15 th, 1867.

By Rev. C. S. LYMAN, M. A., PROYKSSOR OF INDUSTRLA MECHANIOS AND PHXSICS.

NEW HAVEN.

PRINTED BY TUTTLE, MOREHOUSE - TAYLOK. 



\section{Shetrizld Schentific School of Yale Colugex \} July 18th, 1867.}

Prof. C. S. LyMaN :-

Dear Sir-The undersigned, members of the Graduating Class of the Sheftield Scientific School, were greatly pleased with your address at the Anniversary of the School on Monday last, and would respectfully request a copy for publication.

Yours, respectfully,

D. H. WeLLS,

S. H. Chittrenden,

JNO. K. BeEson,

J. T. WHITLESEY,

P. H. Grove,

Alfred CaLDWELh. Jr.,

R. M. Grovk,

L. S. FERRY,

S. I. SYITH,

C. H. HubBarD.

L. H. WOOD,

V. G. BARBOUR.

Wy. G. MIXTrR.

Shgrtield SCIEntifio School of Yale COLLegk ? July 19th, 1867.

(tENTLEMgN:-The address 80 kindly referred to in your note of yesterday, was prepared solely with a view to delivery on the occasion named, and with no thought of its ever going to the press. Yet, if the views presented in such form, and so imperfectly, are, in your judgment, calculated in any degree to awaken public attention to the importance of scientific education, I willingly submit the manuscript to your disposal, with many thanks for your friendly interest, and my best wishes for your professional success.

Very truly yours,

C. S. LYMAN.

To S. H. ChuTrendBN, and others, members of the Graduating Class in the S. 8. S. 


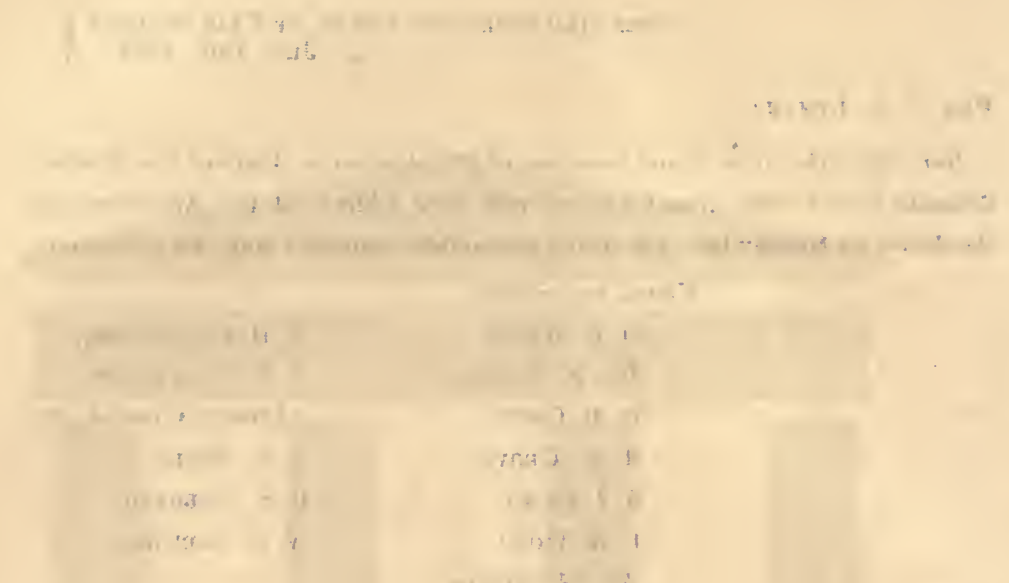

Digitized by the Internet Archive in 2007 with funding from Microsoft Corpöration

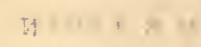

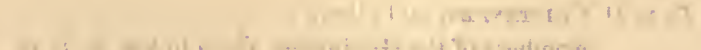

http://www.archive.org/details/scientificeducat0olymarich 
Tuв Anniversary exercises of the Sheffield Scientific School were held on Monday, July 15, 1867, in Sheffield Hall. 'I'he theses and prize essays of members of the Graduating Class were read in the presence of His Excellency the Governor, His Honor the Lient. Governor, and other members of the State Board of Visitors, the President and several of the Fellows of Yale College, and an assembly of gentlemen and ladies. These exercises wore followed by the delivery of the following address.

Those who are not already acquainted with this department of Yale College, may be interested in knowing that by the liberality of Jos. E. Sheffielo, Esq., of New Haven, and other gentlemen, and by the grant of public lands appropriated to the State of Connecticut in aid of scientific education, opportunities are here afforded for the professional study of the various branches of Natural, Physical and Mathematical Science. A report is annually made to the Legislature, setting forth the operations of the School. 



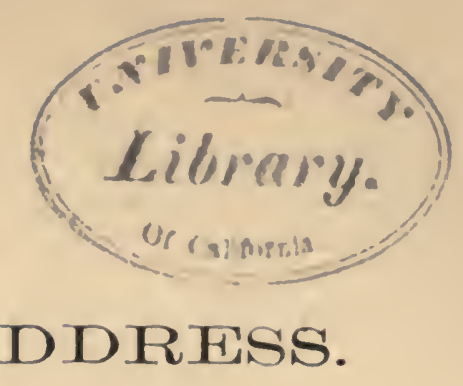

\section{ADDRESS.}

\section{Ladies and Gentlemen :}

Appearing before you to-night, at the request of my associates, to close these Anniversary Exercises, I invite your attention to some thoughts which have occurred to me as suitable to the occasion, but which pertain rather to the practical and utilitarian side of life and learning than to the æsthetic and imaginative. For this feature of them, howcver, I deem it unnecessary to apologize, since naturc herself teaches us, by innumerable examples, that there is, in her domain at least, no necessary antagonism between the Useful and the Beautiful; between those qualities of things by which they minister to man's physical wants, and those by which they gratify his tastes, and his intellectual and moral susceptibilities On. the contrary, she more commonly exhibits the two in closest harmony. Beautiful blossom and nutritious fruit are borne by the same tree. The useful potato rejoices in a delicate flower. The same substance that, as coal, drives our engines and warms our dwellings, as diamond, adds luster to the charms of beauty, and splendor to the coroncts of kings. The stream, that woos the poet to its shaded brink, and inspires him with the music of its flow, turns also the laboring millwhcel, and ministers assiduously to the success of industry. The sun, that flushes the dawn with rosy light. and in his glorious rising bathes the earth and the heavens with beauty and gladness, serves also, as an index on a dial, to divide out for man the indispensablc altcrnations of day and night, of 
summer and winter, of seed time and harvest, and is to the world the inexhaustible source of those subtle energies which play so essential a part in all the vital and physical phenomena of the globe, and without which the globe itself were but a realm of perpetual silence, darkness and death.

And the same harmony that thus holds between the useful and the attractive in nature, holds also between their correlates, the practical and the speculative, in science; for science is but the revelation of nature-the formal expression and embodi ment of her facts and laws. Science has, therefore, like nature, both a practical and a speculative side-an aspect of utility, as well as of attractiveness and beauty; and, hence, that training in science must be essentially defective which does not recognize this fact, and impress the corresponding qualities upon the character of the student. The student of science, rightly trained, will be, in fact; both a theorist and a practical man in the proper sense of that term; a cultivator of science for its own sake, and also for its uses, in its abstract and speculative forms, and in its applications to the arts of life. The two correlated qualities fitly supplement each other in his education, and conspire to prepare him for more certain success in his career.

Not that he must preserve, necessarily, an exact balance between the two, and never become, distinctively, either the one thing or the other, either a devotee of abstract science, or a thorough man of business, if his tastes, his talents or his circumstances so incline him. He will, if wise, follow his bent, and allow either the one element or the other to preponderate in his professional life, as he shall see fit. Possibly, he will specially devote himself to pure science, pursuing it for the mere love of it, and bringing himself, with all the zeal and enthusiasin of Newton over his soap-bubbles, or La Grange 
over the intricacies of the Calculus, to the elucidation of phenomena seemingly the most trivial, or relations the most abstract and etherial, undisturbed by the invidious question, cui bono? - or by the inability, either of himself or others, to perceive at once the utility of his results. Or, on the other hand, he will, if he choose, engage, heart and soul, in applying science to the arts of life, and concern himself with new facts and principles only as he sees in them new means of aiding industry, and opening up the resources of trade and commerce. In either case, he will find full scope for his utmost energies. But his success as a theorist' will be all the more certain, if he constantly test theory by the problems of practice, and his efficiency as a worker for unaterial progress will be in no wise diminished, but rather enhanced, if he pay court to abstract science, as he shall have opportunity, and treat her as befits her native dignity, not as a mere drudge. Newton, the prince of theorists, was also one of England's most efficient Masters of the Mint. The notion that scientific men are inere visionaries, and unfit for the business of life, is one of the prejudices of the remote past, and can never be revived, while a symmetrical training shall characterize our schools of science.

These prefatory thoughts on the relations of the theoretical to the practical in science, and in Scientific Education, while not unsuitable to be borme in mind by those about to leave the institution and enter on the active duties of life, serve also fitly to introduce the theme to which I now nore particularly invite your attention :-

\section{Scientific Education in its Relations to Industry.}

The increasing demand for scientific instruction in our systems of education, at the present day, is a noteworthy and 
significant fact. The strength with which the tide of opinion is setting in this direction, cannot have escaped the attention of even the most unobserving. The frequent and earnest discussions as to the relative value of classical and scientific studies; the pressure on the Colleges to replace the classics with studies of a more practical character; the disposition of some of them to acquiesce; the numerous institutions, more or less distinctively scientific, rapidly springing up in all parts of the country, and the frequent engrafting of schools of science on the existing literary institutions ; in England the parliamentary commissions on the state of the schools and universities, with theirsignificant reports ; and in this country, the enactments of Congress, and of State Legislatures, in behalf of Colleges for the promotion of agriculture and the mechanic arts, are all so many unmistakable signs that on this subject a great revolution is going on, not only in the general public sentiment, but also in the minds of educated and influential men. It is obvious that the jrogrammes of education for American youth in the future are to be different from those of the past. The demand for more science is imperative, and cannot be ignored.

This demand has obviously arisen, partly from the rapid development of the Sciences in recent times, and the conseqquent extension of the boundaries of human knowledge; and ,partly from the growth of the Arts with advancing civilization, and the consequent demand for new applications of Science in aid of these Arts, and of the general operations of industry.

It is to the first of these considerations that we are to ascribe, chiefly, the call for more' Science in our systems of liberal education, and to the second, the demand for schools of applied Science, and a more practical education generally. 
A discussion of the first, named point-the relative merits of classical and scientific culture-is foreign to $\mathrm{my}$ present purpose, though indirectly bearing on my subject, and demanding, certainly, the thoughtful consideration of all who are made responsible for the education of youth, in these, the United States, and in this, the 19th century. Earnest men, alive to the vastness and rapid growth of the republic, and to the proud position it holds among the nations of the earth, as well as to the importance of our vast agricultural, mechanical, and manufacturing industries, are pressing the question with startling emplasis, Why is it, that languages ten centuries dead are thought better than German and Freneh to fit an American ambassador for the eourts of Berlin or Paris? Why is it, that the dead mythologies of the dim old ages of fable are thought better than the ripe seiences of to-day-the garnered fruits of centuries of toil and miraeles of genius-to fit living men for the work of life, in these stirring times? But to such questions I refer, simply to say, in passing, that total banishment of the classics is by no means necessary to the purpose of those who would give due place to the seienees. However certain it may be that classical culture will in time become of less commanding, if not of secondary importanee, from the relative growth of other learning, it has already too long held its acknowledgred position of preëminence, and become ton thoroughly inwrought into the whole texture of the world's literature, to be wholly set aside as useless. Far, far distant be the day, when old Yale shall no more impart that culture in the polished turgues of Homer and Horace, which has given strength, and breadth, and beauty to scholarship, all down the centuries, and in all civilized lands. Far distant the day, when the iconoclasts shall lay violent hands on that symmetrical and well compracted system of training, which, rightly 
blending the graces of the bygone literatures with the strength and richness of the philosophies and the sciences of later times, has sent forth from her venerated halls so mally generations of scholars, to grace with their ripe culture the learned professions, as well as the authorship and the statesmanship of our land. It is not supplanting that is needed, so much as supplementing, cither in Yale, or elsewhere. The aim of the reforming architect should be, to build on, rather than to pull down. The old curriculum should be maintained, for those who choose it ; and cnough, doubtless, of classical candidates will always be found to fill the classes. But there is room, in our civilization, for more than one type of culture. New curricula must meet the new demands and changed circumstances of the times. Yale College, it seems to me, has already taken the right course. Always progressive, and like other American Colleges, from the very first, less predominantly classical, and more largely mathcmatical and scientific in her training, than the English Colleges, she has been the first to recognize the importance to Amcrican industry of schools of practical science; and this young branch of the university is proof, to-day, alike of the growing demand for a broader training in the sciences, and of the readiness of this ancient seat of learning to meet that demand to the full extent of her ability. Private munificence has given her these commodious halls, and the State has added the Congressional bounty, to enable her to teach here, to the rapidly increasing classes, those branches of lcarning that relate to the great industries of the day, particularly to agriculture and the mechanic arts.

It is the distinctive work, then, of this institution, simply to meet the wants that gave it birth-in a word, to utilize science-to tcach it in its practical applications-to make it instrumental in promoting human welfare-especially, as that 
welfare is dependent on successful industry. And this, also, is the distinctive work of the many similar institutions that, under the fostering influences of private liberality and public bounty, are springing up in other States, and are variously known as Polytechnic Institutes, Schools of Industrial Scienee, Sehools or Institutes of 'Technology, Scientific Schools, Agricultural and Mechanical Colleges, Schools of Mining, and the like. They are all organized and administered on the assumption, that Scientific Education is of vital importance to civilized industry. Is this assumption eorreet?

I propose to show that it is-that a prime element in the success of industry is scientific knowledge-in other words, that, in view of the relations actually existing between the scienees and the arts of life, the industrial world is right in looking to the scien ses and to scientific institutions for aid in the future development of its resonrees.

In what I have to say on this subject, it is not my purpose to exalt seience, or scientific training, at the expense of practical experience. Each has its appropriate work. Science has sometimes, doubtless, been too indiscriminately lauded, and results aseribed to her agency, for which she could not justly claim credit. To assume that all progress in the industrial arts, and all the blessings they have conferred on man, are the sole and direet fruits of seienee, is to take ground which a just discrimination and the facts of history do not warrunt.

The truth is, that when we examine the several arts we find them indebted to the sciences in very different degrees, and some of them searcely at all. The arts may be arranged, then, as it respects their relation to the scienees, in two classes- the empirical and the scientific; the first, the mere results of experienee-the seeond, of experienee controlled by general principles ; the first, embracing the simpler and more necessary 
handicraft arts, which are easily originated, and belong to the rudest stages of society, requiring few tools or implements, and no machinery, Such are the simpler forms of agriculture, the arts of making rude tools and utensils, of braiding mats and twisting cords, of constructing huts, cooking food, and the like. These arts are the first offspring of necessity-the result of man's earliest efforts to subsist-requiring little thought, less knowledge, and no science. The second class includes the higher and more complex arts peculiar to civilized society. These are many of them the growth of centuries, involving not only the results of long and varied experience, but profound knowledge, also, of the facts and principles of science. Many of them have been called into existence by the newly developed wants of advancing civilization, and their existence has been rendered possible, not unfrequently, only by new discoveries in science, or by the development of new sciences. They may be called, therefore, distinctively, scientific arts. Such are the modern arts of navigation, constructive mechanism, telegraphy, photography, electro-metallurgy, steam engineering, and countless others, to each of which many sciences and many other arts have made their contributions, as links to a chain, any one of which being wanting, the art could not exist, or exist only in a much lower stage of development.

The former class-the empirical arts-are, in their ruder forms, not only little indebted to the sciences, but most of them, in their origin, older than the sciences; in accordance with that general law of progress-the crude before the finished-the practical before the speculative-the supply of wants before the gratification of tastes-the fruits of poverty before the results of ease and affluence. There was land measuring before geometry, bread making before chemistry, machines 
before mechanieal seienee, doctoring and dosing before a science of medieine. Agrieulture, as an art, is as old as Eden ; as a seienee, the child of to-day. Metallurgy as an art, is eo-eval with 'Tubal-Cain; as a scienee, an offshoot of modern ehemistry. There was, properly, no science of mechanics, at least in the modern sense, when the ponderous stones of the Pyramids were hoisted to their places, and there was nu proper scienee of arehitecture when the grand eathedrals of the middle ages were ereeted. Yet the Pyramids still stand to proelain to us the high antiquity of mechanies as an art, and the wonderful domes and arches and columns of the medieval arehitecture, attest emphatically the perfection, even then, both of the art of building and the genius of the builders.

And so, always, in a new and forming state of society, the arts eome first, the seienees afterwards; as our own country exemplifies. The woodman's ax and the carpentor's adz transformed forest trees into dwellings before the botanist settled their genera and speeies, or the seientific arehitect eame with his estimates and drawings. The farmer's plow did not wait for the analysis of soils. The people built for themselves ships before they did observatories; and searehed oceans and eontinents for eommeree before they did the heavens for stars. Societies and Fairs for the eneouragement of Arts and Manufactures were instituted long before the "Ameriean Association for the advaneement of Seienee" began to meet, or the "National Academy" was founded by Aet of Congress. And mills and faetories were built, and maehine shops in operation, before ever we began to hear of Sehools of Seienee, or Institutes of Teehnology.

And so of individual men. The artifieers and inventors of the world-the men who revolutionize human industry and manifold the wealth and power of nations by new machines 
and new processes of Art-these have not always, nor yet even often, it must be conceded, commenced their career as men of srience. The Watts, the Arkwrights, the Bramahs, the Clements, the Nasmyths, the Stephensons, the Fairbairns, the Fultons, the Erricsons, the Goodyears, the Howes, the McCormicks, have usually had their training in the shops, not in the Schools. As Isaac 'Taylor phrases it, "The great Inventor is one who has walked forth upon the industrial world, not from universities, but from hovels; not as clad in silks and decked with honors, but as clad in fustian, and grimed with soot and oil."

What then, you will ask, is the use of scientific training ? Why palter with Theory, when Practice can accomplish such marvels without it? Why Colleges to train Engineers, when the great giants of engineering have grown up outside of Colleges ?

In the first place, I answer, the great engineers and inventors named, though, for the most part sprung from poverty, and trained mainly in the shops, have not accomplished theil results independently of science. They did not come from College, it is true; they did not study science in the classroom. But, nevertheless, they did study science. They found opportunity, in the midst of laborious occupations, to acquire, as they needed them, at least its rudiments and its results. Gifted with high genius and indomitable energy, they, in spite of obstacles, pushed their way upward, often stumbling, it is true, yet gathering new knowledge by the dear-bought experience; conning the science they needed by the light of the forge, or the midnight torch, or at early dawn; and when their own scanty stock failed them, calling to their aid the profounder scientific acquirements of men trained in the Schools. Most of the great English Engineers, though thus gathering their knowledge only in the midst of active business, 
have ultimately, from the very necessity laid upon them, become in reality men of science-some of them, even of eminence in science.

Watt owed his memorable success in improving the steam engine, mainly to his persistent investigation of the laws of heat and steam. Distinguishing limself, not only as an inventor, but ultimately as a scientific discoverer, his name, in later life, adorned the catalogues of many learned societies, while his scientific papers enriched their transactions.

James Nasmyth, too, so well known as the originator of those wonderful machine-tools for planing and shaping the metals, which have so totally revolutionized mechanical engineering, though, at sixteen, only able to attend a few scientific lectures in the University of Edinburgh, on tickets bought with models of stean engines which he made for the purpose, and forced to acquire annid the din and bustle of the shop most of the science he needed in his professional practice, yet also, like Watt, in later life, stepped forth from the shop into the halls of science, and even more, into the galleries of elegant arts. An admirable painting of his in a late London collection, a learned paper before the British Association, on the cuneiform characters of Babylon, discoveries in the sun, Inade with a telescope of his own construction, and pronounced hy no less an astronomer than Sir John Herschel to be "most wonderful," all attest that his great distinction as a practical man was not achieved by ignoring science and books.

And William Fairbairn, also,-for the last half century among the foremost of Eitglish Engineers-a man who began life in poverty as a traveling millwright, and who at length by lris originality and enterprise, became in a sense, the father of the noderis system of mill-work-a system characterized by its light iron frames and shafting, its iron hangers, iron gearing, 
and iron water wheels, and which, by increasing the speed of machinery from forty to three hundred revolutions a minute, has increased in proportion the productiveness of the mills, not only of Manchester and Birmingham, but of Lowell, and all christendom as well-even Fairbairn did not succeed without science. Though emphatically a man of the workshop, he has long since, by his genius and the earnest devotion of his odd moments to study, become substantially, a man of science, and has always employed the utmost resources of his scientific knowledge, in his professional practice. Though distinguished for his researches in experimental science, and the author of works which have made him a leading authority in some branches of engineering, particularly mill-work and iron architecture, he yet, after a most brilliant professional career, deeply laments his lack of early scientific training, and expresses, by implication, his opinion on the question before us, when at the age of sixty-five, (he is now eighty) in urging on practical men the diligent acquisition of scientific knowledge, he says, "You need not be surprised when I assure you, that after nearly fifty years practice, I am still learning, still at school, an 1 I believe must continus so, until the great book of nature closes upon me forever."

Other illustrations, to the same point, might be drawn, ad libitum, from other fields of industry.

Knowledge of science then-as the career of even the most eminent self-made men exemplifies-is really a prime element of success in all departments of industry.

And the concession made, that some of the ruder arts are older than the sciences, and that genius and energy can accomplish much in spite of deficient scientific training, is, in truth, no argument to the contrary, especially when we consider further, that these ruder arts, however important in 
themselves, and however extensively practiced among inen, are. after all, not those which ehiefly characterize eivilized nations. and on which the progress of sucl nations in wealth and power chiefly depends. The arts of civilization are those which wc have called distinctively seientifie arts-arts involving the applieation of scientific prineiples-the substitution of nature's forees for humau strength--of the exaet working of mechanism for human skill-arts, therefore, in which seientific knowledge is of the first importanee-in which brain-force has more to do than muscle-arts, in short, that verify the apothegm, "Knowledye is power."

Of these, one portion consists of the older arts revolutionized by science-so revolutionized, indeed, as to be virtually new. Navigation, with its eompass, chronometer and steam ; husbandry, with its ehemical analysis, its mechanieal harvesters, and other like appliances; textile manufaetures, with their jennies and mules, their power looms, and water-wheels, and steam engines; bleaching and dyeing, and the working of ores and metals, with the aid of ehemistry ; in fine, the great body of the older arts: under the transforming power of the modern scienees, bear but little resemblance to what they were in the early stages of their growth. Even when the old process has been essentially retained, the scale of operation is such as to render the art substantially new, as an element of industrial success. The processes of the old steel-workers of Dannascus, though turning out blades of rarest temper, were rude, doubtless. as compared with those of Sheffield-slow, as compared with Bessemer's. From the ancient distaff, it is a long stride of progress to the mills of Manehester ; and squally long, from the horse or the ox to the steam engine, from the cart to the rail-ear, from the coasting galley to the ocean. steamer. 
The steps of transition from the ancient arts to the modern, are the steps, essentially, of man's progress in science and civilization. The genesis of civilization is, indeed, the genesis both of the sciences and of the modern arts. There has been for each a natural process of development and growth. Science has sprung, primarily, fiom man's innate activity of thoughthis desire to know; the arts, from the physical circumstances in which he is placed-his desire to improve his condition ; and civilization, in its physical element, apart from the moral, is the child of the two. Their mutual relations to each other are best seen perhaps in the circumstances of their origin and growth. The arts, as I have said, are the offspring of human wants-artificial wants, not less than natural. Many of them, indeed, had had no existence, but for the wants which civilization creates; and conversely, civilization itself had made but slow advances without these arts. Were there no wants, indeed, there were, obviously, no need of arts or industry. Were man in the ideal perfect state, so apt to be conceived by the over-tasked laborer-that of the oyster-nothing to do-no wants not directly supplied by nature-or, taking in the moral element, that of Adam in the Garden-his need of applied science were, indeed, small. But Adam's posterity exists, as we only too well know, under the inexorable law of toil. With the heritage of toil, however, God gave man, also, dominion over nature, and commanded him, not only to replenish the earth, but to subdue it. Subdue it-and bravely has he striven at the task; and the history of his successes,of the reduction, step by step, of the forces and the resources of nature to human control, - has been the history. substantially, both of the sciences and the industrial arts. First, the mastery of the hand, then of animals, then of wind and water, and lastly, of steam and the subtler forces of electricity and mag- 
netism-these are the successive steps of subjugation. The earliest mills were driven by the gentle hands of women. Woman shared with the ox the burdens of domestic toil. What rejoicing when the next great step of conquest was achieved, and water made to take her place at the stones ! How lieartily does the old Greek poet congratulate the female sex (n) their emancipation from this form of drudgery! "Woman!" he exclaims witl enthusiasm,-_ "You who have hitherto been employed to grind corn, for the future, let your arms rest. It is no longer for you that the birds announce by their songs the dawn of the morning. Ceres has ordered the river nymphs to move the heavy mill-stones and perform your labor."

And thus has been hailed each successive triumpli of man over uature, from that day to this-when the rejoicings of the world over the victories of steam and magnetism-the sublime power of our modern enginery, and the magic achievements of the telegraph-are still so fresh in our memories.

In this long struggle of man to improve his condition-to realize the high ideals of comfort and enjoyment which his imagination paints for him<-he is doing a two-fold work. At one time he sets himself to the single task of overcoming the obstacles he meets - of inventing instruments and processes for attaining ends beyond his immediate reach. At another, he lingers to examine phenomena that arrest lis attention, learns their laws, discovers their relations to the results he is seeking, and obtains hints for the devising of new processes, and still more powerful means for attaining his ends. In the one capacity - as an inventor-he is developing the arts; in the other-as a discoverer-the sciences. But, at a certain point of progress-the point of separation between barbarism and civilization-the increasing difficulties and complexities of both lines of effort, require virtually a division of labor. In 
the more advanced stages of society, the two kinds of exertion are made by different minds. One set of men take to the arts, another to the sciences. They both labor for a common end. They are each dependent on the other. The philosopher must have instruments of research which only the artificer can make, and the artificer, facts and principles, which only the philosopher can furnish. Each art is dependent, in fact, not on one science only, but on many sciences, and each science contributes aid to, and receives aid from, many different arts. In general, the arts and their related sciences keep step togethernavigation, with astronomy-mill-work and manufactures with mechanical science. And conversely, the sciences can only advance with the arts that supply their instruments and apparatus of research. Chemistry must needs have her blowpipes and furnaces, her crucibles, retorts and balances; and astronomy, her telescope, circle and clock. Physiology, animal and vegetable, is blind without the microscope. And even the mathematics, so preëminently abstract and dissociated from material things, can yet stoop to the use of mechanism, and grind out numerical results, like coffee, from a species of mill turned by a crank - the calculating engine.

While the sciences, then, freely acknowledge their obligations to the arts, let the arts, also, give due credit to the sciences. The true relation between them, as we have seen, is that of co-workers for a common end; co-partners, if you please, in the rreat business of advancing the welfare of man. Science does her part of the work, we may say, chiefly in the office; art, hers chiefly in the shop. Science furnishes the brain, art the brawn. And the greater, and more difficult, and more exacting the work, the greater the need of sound theory at the desk, as well as sound practice at the bench-of science, as well as skill and energy, for the perfection of indus- 
trial progress. The cobbler's stall and the village smithy require no office. The simpler arts go on with very little science But not so the more complex and difficult. The mills of Lawrence, the arsenal at Springfield, the Novelty Iron Works, the Government Navy Yards, require plrofound theoretical training in the guiding head-brain-power backed by all the resources of science-to meet the exigencies of moderr civilization.

But, again; of the modern arts to which I have referred, those on which our present industries chiefly depend, no inconsiderable portion are entirely new, and, most of then, the direct progeny of the modern sciences. Photography, telegraphy, electro-metallurgy in all its varieties, chemical manufactures, steam engineering, and other arts alnost numberless, we recognize as almost purely the gifts of science to the world.

Take the art of utilizing the power of steam. Who can estimate the obligations of the world to physical science for this single benefaction? Think of the revolutions it has already achieved, and the progress it has reudered possible in every departinent of human industry. It is the steam engine, indeed, that, more than anything else, determines, in modern times, the wealth and power of nations; the steam engine that has enabled England to lead the world in manufactures and commerce; the steam engine, that, by propelling our transports and our iron leviathans, and sending swiftly over the rail our vast armies, and pouring from thousands of factories wealth into our national coffers, formed an indispensible auxiliary in erushing for us the slave-holders' rebellion, and saving the republic. Who indeed can gauge or define its power? How magniticently it has widened the field of human enterprise! How many hundred fold it has multiplied, on every 
hand, the productions of industry ! In the words of a eulogist of Watt, of half a cen tury ago: "It has increased indefinitely the mass of human comforts and enjoyments, and rendered cheap and accessible all over the world the materials of wealth and prosperity ; it has armed the feeble hand of man, in short, with a power to which no limits can be assigned; completed the dominion of mind over the most refractory qualities of matter, and laid a sure foundation for all those future miracles of mechanic power which are to aid and reward the labors of after gencrations." If this was true half a century ago, how much more true now, when engines like the Great Eastern's, contrast with the grandest of Watt's, as giants with pigmies.

But the steam engine is only one of thesc direct contributions of science to industry. Time would fail me to speak of others, or to enumerate the special gifts of particular sciences to particular branches of the arts; often of apparently the more unpromising departments of scicnce to the older and more common of the arts; as, from the chemistry of coal, the beautiful aniline dyes, which give such brilliancy and variety of coloring to our silks and other textile fabrics; from the abstract theory of the polarization of light, an instrument for measuring the comparative sweetness of sugars; and from the physics of combustion, the safety lamp of Sir Humphrey Davy, which has saved so many thousands of lives and so many millions of wealth, in the hazardous operations of mining. But even more than to any other class of sciences, the industrial world is indebted to the mathematics, from arithmetic and geometry up through algcbra and the calculus, to the highest branches of analysis; a class of sciences lying at the very foundation of no small portion of the other sciences, and constituting the most potent instrumentality we possess, for opening up nature's laws, and enabling man to avail himself of her 
resources $\rightarrow$ class, which, in the benefits it confers upon the arts, and through the arts again upon man, stands almost alone-the noble offspring, not of the arts, not of other sciences, not of nature even, but purely of the human intellect. Without the mathematics, there were no mechanical or engineering science, and hence, but a limited practice; no astronomy, spherical or physical, and consequently, no navigation and no foreign commerce. They underlie, in fact, directly or indirectly, the whole structure of modern civilization ; constituting the basis of no small portion of that knowledge and power which make man what he is, and enable him, in 80 wonderful a degree, to control and utilize the forces around him. No one, who would be a master in any department of the industrial arts, particularly the mechanic arts, can be too thoroughly versed in the mathematics, especially in their practical applications. Not that every hand on the farm, or in the shop, need study the calculus, or even algebra. There are thousands of good workmen, who know nothing of either. But, nevertheless, the more even the humblest workmen knows of the mathematical and scientific theory of his work, the more likely he will be to originate improvements in its machinery or processes, and the more likely, also, like others in similar circumstances, to secure for himself, with increasing culture, both an honorable name in his calling, and position and influence among men.

But, besides the considerations that have been touched upon, showing in general the close interdependence of the arts and sciences, and the importance of scientific knowledge to the success of industry - considerations applicable to all times and countries-there are others that relate more especially to the circumstances of our own country, and show the growing importance of schools of practical science among us, analogous 
to those which have been so long in successful operation in France and Germany, and those which, more recently, have been springing up in Great Britain, under the pressure of her well-known bitter disappointment and mortification at the results of the Exhibition of 1851 .

These considerations turn mainly on the present condition of the country in respect to its several industries, and the rapidity of its growth in population and wealth. The industrial arts in this country have, in the main, overtaken those of Europe, and in some departments surpassed them. The same may be said of the sciences. There are few things, from a pin to a piano, or a telescope, for which we are now compelled to cross the Atlantic. The tide has even set the other way. We now make telescopes for the most eminent of English astronoıners, pianos for the star-musicians of Europe, rifles and locomotives for the Czar of all the Russias, Dunderbergs for Louis Napoleon, and crinoline for his Empress. Our clocks tick in every land, our revolvers and repeaters enforce everywhere respect and admiration, our commerce in india-rubber fabrics has stretched itself to the ends of the earth. Our manufacturers are no longer compelled to label their sewing silks Italian, or their ivory combs British, or their porcelain and broadcloths French, to give them currency in our own market. At the world's grand pageant in Paris, the other day, American art was complimented with gold medals from imperial hands, for eclipsing the world in pianos, sewing machines, telegraphic apparatus, reaping and mowing machines, steam-engines, and other products of inventive genius and mechanical skill. And the aggregate products of our arts and manufactures, as well as of our agriculture, are rapidly increasing from year to year, and increasing in a much higher ratio than our population; and that is increasing at a rate that startles us with the aggre- 
gate it promises within the compass of a single generation; an aggregate, at the present and past ratio of increase, of a hundred millions at the end of the century. T'he valuc of our manufactures was nearly doubled between 1850 and 1860 , and that of our agricultural products nearly four-folded in the same time. In 1860, the former amounted to $1900,000,000$; equal to more than two-thirds of the debt saddled upon us by the rebellion Indeed, nothing connected with the rebellion morc astonished the old world, than the revelation it made of the almost unlimitcd resources of our arts and manufactures, as well as of our agriculture. At the present tinc, more than one-third of our entire population is supported, directly and indirectly, by manufacturing industry ; and it is this department of industry, perhaps, morc than any other, that is directly benefitted by science. The increasing activity, also, of the inventive talent of the country, is seen in the ever-expanding business of the patent-office-the number of patents issued last year being nearly 10,000 - an increase of 50 per cent. over the year before; and here again, science has an important work to do, in preventing the waste of this talent (as it too often is wasted) on uscless or impracticable contrivances.

We have rcached a period, then, as a nation, when the ruder and more wasteful forms of industry will no longer suffice. Though, in a fertile and sparsely settled country the cxuberance of nature makes amends for deficiency of economy and skill, that time for us is past. . With the growth of population and the increase of competition in every department of industry, our arts and manufactures, as well as agriculture, can no longer aftord to retain the uncconomical methods of former times. Success can be secured, now and in the future, only by carefully adjusting the cost of production to the market pricc. And to this end, not only the management of the processes, but 
the construction of the machinery, and all the means and appliances of manufacture, must be controlled by educated skill, especially in all those leading establishments, where the more difficult and complicated processes of industry so naturally center.

Both the extent and present stage of progress, then, of our arts and manufactures, require for their further improvement, not only the highest personal talent and energy, but the utmost resources of applied science. Qualifications that once would answer for the head of a great manufacturing establishment, will not do now. The present generation is obliged to know a great deal more than the preceding. The brain-power that is to manage our arts and manufactures, our agriculture and commerce, in their broadér and more difficult future development, must be trained for the task;-and the more the brainpower preponderates over mere muscle, the more elevated will become both arts and artizans, and the more marked the influence of science and scientific education on the progress of the nation in wealth, intelligence and power. Indeed, if I am not mistaken, the true solution of the vexed question of labor, and of the elevation of the industrial classes, is to be found, in part, at least, rather in an increase of the productive capacity of the industrial arts through the applications of science, than in any arbitrary eight hour law, or other legislation against the laws of nature. The more man can substitute hearl work for hand work, and compel nature's forces to perform his tasks, the more he will shorten his necessary hours of labor, and add to his leisure for recreation and self-improvement.

But I must hasten to a close. The future of this country, in respect to material prosperity, is obviously to depend largely on the efficiency of the industrial arts, and that efficiency, on the progress of the sciences, and the extent of their diffusion among 
those who control the operations of industry. There is no reason to suppose that both science and the arts will not make as great advances in the future as in the past. Each generation glories in discoveries and inventions that were unknown to the preceding. Who dreamed, fifty years ago, that we of to-day would receive, with our morning coffee, the last evening's news from London and St. Petersburg? or that our country, with all its' vastness, would be, to-day, through the shrinking eflicacy of railroads, virtually smaller, in respect to accessibility and ease of government, than was the State of New York, oromitting the territories on the Pacific-than was even the State of Connecticut, in the days of the Revolution? Who dreamed that by the aid of light and a few chemicals, we should take instantaneous pictures, not only of the "human tace divine," but of Hying cannon balls, and volcanoes in the moon, and world-systems so far away, that the picture we get shows not their aspect now, but that of years or centuries ago, when the imprinting rays first left their distant source? Who dreamed of our Great-Easterus, and Dictators, and Dunderbergs-our terrible repeating rifles-our lightning printingpress - our mechanism for setting and distributing types, and even for printing without setting and distributing types, by electrotyping a matrix, into which, letter by letter, the "copy" has been struck, by the simple fingering of an alphabetical key-board, an American invention now attracting attention at the Great Exhibition in Paris ? 'Who dreamed of our marvelous automatic machinery for making pins, needles, and fish-hooks-our busy sewing-machines in every family - our reaping, mowing, raking, binding, threshing, winnowing, and other agricultural inachinery for lightening and accelerating labor?

And why may not the next half-century note progress as great its the last, or even greater? Nature's secrets are not yet all 
revealed to us; - her forces not all discovered-certainly not all subjugated. Heat gives us, in the steam-engine, but a fifteenth part of its intrinsic force. Some new mode of transforming energy may utilize a larger percentage. To the triumphs of invention we can set no limits. What new arts, new processes, new materials, new mechanism, will hereafter revolutionize industry, and manifold the mass of human comforts and enjoyments, who can tell? With our country all free; labor nowhere degraded as a badge of servility ; our vast coal fields just beginning to be opened ; our mines of gold, silver, copper, iron, lead, zinc, and other important metals, waiting to yield up their treasures; our vast agricultural and manufacturing interests rapidly augmenting, and more and more aided by new applications of science; the broad South, full of running streams and fertile plains, open to manufactures and the mechanic arts, as well as to agriculture; our entire population, from lake to gulf, and from ocean to ocean, increasing, from year to year, in homogeneity and community of interests, as well as in numbers, intelligence and wealth; with all these bright omens, and others like them, to guide us, how can we fail to discern a future for our country, that needs no imagination to give it brilliancy of coloring, and no spirit of selfcomplacency to commend it to our admiration. With a pure Christianity and universal education as its moral basis, and intelligent industry, guided by sound science and protected by equal laws, as its material foundation, it is a future that may well rejoice the heart of the patriot; and if, towards any of its elements this institution shall be found to have contributed in some humble degree, well may its graduates, its instructors, and its benefactors, find in the fact encouragement to still more strenuous exertions in behalf of the science, the industry, the wealth, the power, the world-wide influence for good, of this great, free, re-united and never-more-to-be-divided country. 



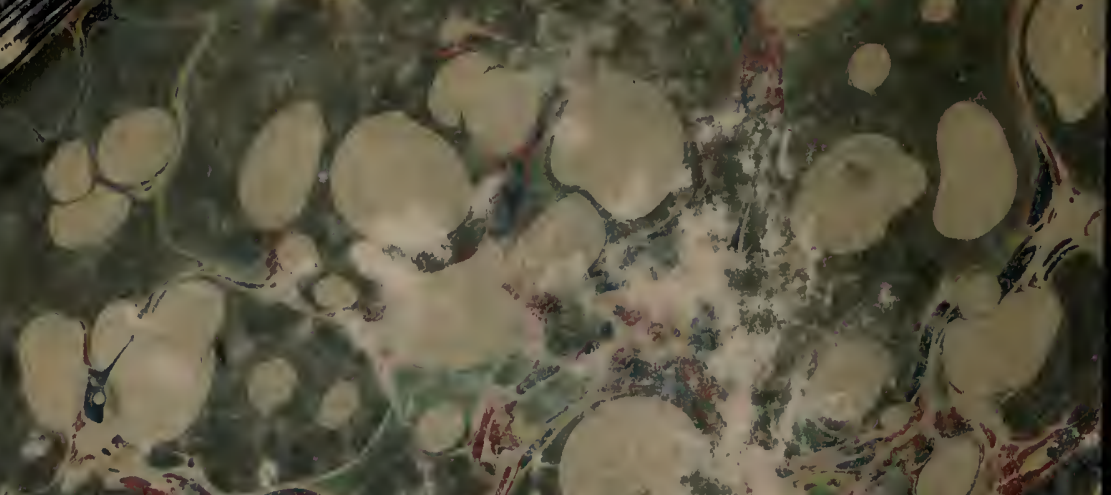
a.

Whon

$\left.x^{2}-3(a) \cdot p^{2}\right)$

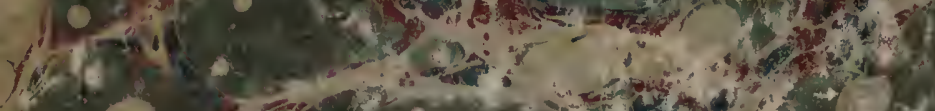

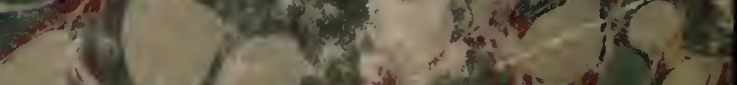

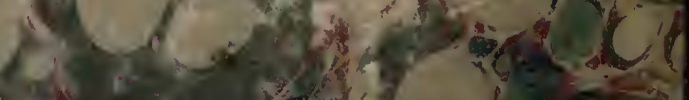

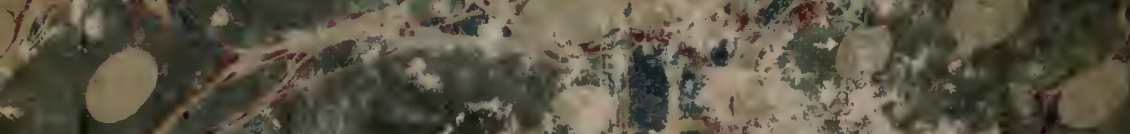

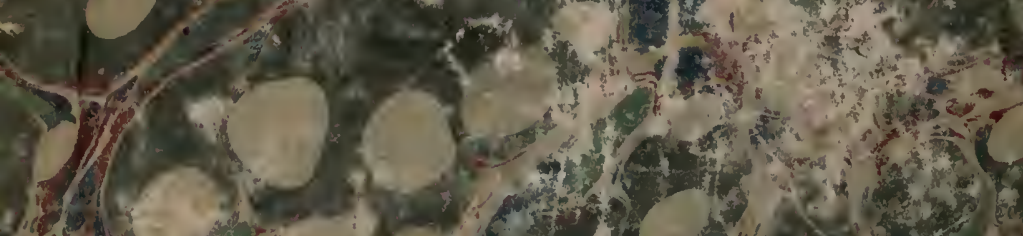

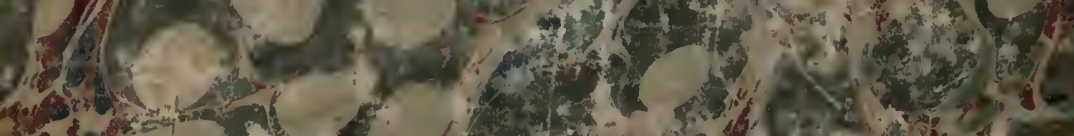

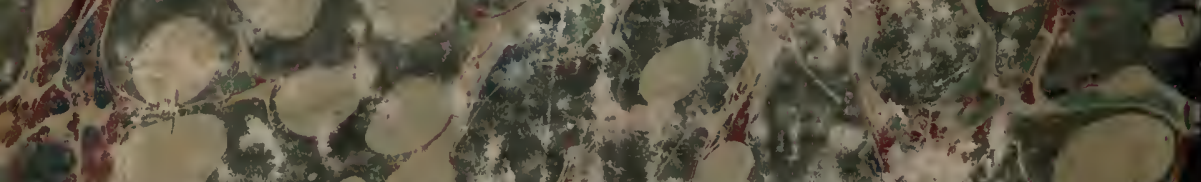
(2)

B)․․․․

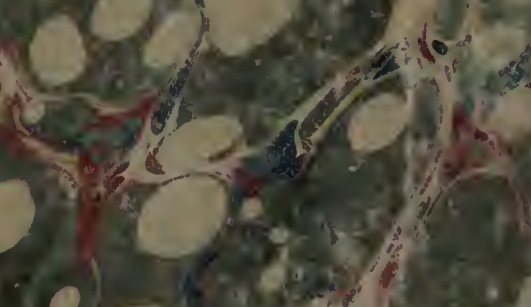

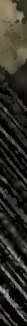

s.

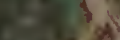

M.

in 10

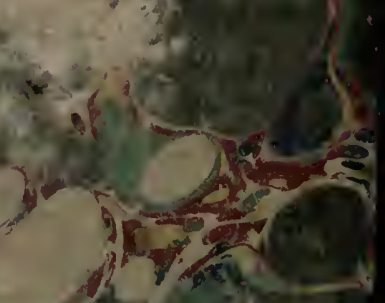

mith

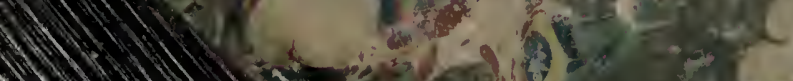

d) -4 .

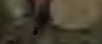

